\title{
History and Politics:
}

\section{Research on the United States in Norway, 1945-1980}

By

Geir Lundestad

University of Tromsø

This essay will deal with Norwegian-American history in the post-war period, not in the form of traditional diplomatic history, but rather in the form of attitudes toward the United States as expressed by Norwegian scholars in their writings on the United States." So this will represent a study in international relations, but on the cultural rather than on the political 'level, although an attempt will be made to say something about the relationship between the two. ${ }^{1}$ I will also go into the relationship between scholarly writings and popular views, as the latter have been expressed for instance in public opinion polls.

It should be emphasized that this essay will take up writings with a clear historical dimension. Studies of American literature as such will not be included. Neither will generally the works of social scientists, because they do not have a strong element of historical chronology and development.

To hold the many levels and the wide time span together, we need some concepts that can focus the information available. I propose to use the concepts of expansion, limitation, and contraction. $^{2} \mathrm{O} n$ the general political level we can talk about expansion in the form of a growing U.S. commitment to and influence in Norway in the post-war period. Yet, this is a study of certain scholarly Norwegian attitudes to the United States, not of Amer-

* This article presents an early and abbreviated version of my essay for the American project Guide to the Study of United States History Outside the U.S., 1945-1980. The project is administered by Professor Lewis Hanke and will be published in 3 volumes. Publication is planned for late 1983 or early 1984. A long section on emigration history will be part of the final essay, but is not included here. 
ican attitudes to Norway. It does not make much sense to talk about Norwegian commitments to or influence in the United States. But we can certainly talk about more or less positive Norwegian attitudes to the United States, and also about varying degrees of interest in America. So, by expansion I mean primarily a more favorable attitude to the United States, and secondarily an increase in interest in that country.

Nevertheless, all the time definite limitations existed on this expansion. Norway rarely occupied center stage in Washington and America's interest and influence in Norway were limited in many different ways. More important for this survey, Norwegians who wrote about the United States almost always had some reservations about that country. Naturally the United States also represented only one among many topics for Norwegian scholars. Based on this skepticism, sometimes even dislike, expressed and a certain lack of interest in the United States, we may talk about the limitations of the Norwegian-American cultural relationship. Those limitations then are not absolute in the sense that they represent the opposite of expansion - which would be contraction - but only point out the many ways in which expansion was held in check.

Proceeding from this, I suggest we refer to four main periods in Norwegian attitudes to the United States. These periods are from 1945 to 1949 , from 1949 to roughly 1965, then from 1965 to the mid 1970s, and lastly from the mid '70s to 1980 . These four periods I will call respectively expansion with limitations, limitations under pressure, the contraction of the Norwegian-American relationship, and, finally, a new balance.

\section{I: 1945-1949 = Expansion with limitations}

Since scholarly attitudes will be compared with the over-all Norwegian-American relationship and with popular Norwegian attitudes to the United States, something has to be said, however briefly, about these two elements.

From 1945 onwards America's role would increase dramatically compared to the pre-war period. Despite this fact, the NorwegianAmerican relationship was rather limited. Britain continued to be the Great Power toward which Norway felt closest, in military as in political and cultural affairs. A significant skepticism to the United States could be noticed among the Norwegian public. In 
a poll taken in August 1947 in Norway, England, France, Holland, Canada, and the United States, no country showed such dislike of the United States as did Norway. Within the governing Labor party a majority even thought the United States more likely than the Soviet Union to strive for world supremacy (64 to 57 per cent). ${ }^{3}$

Considerable changes would take place from late 1947. Norway's participation in the Marshall Plan led to an improvement in Norwegian-American relations. Norway's membership in NA$\mathrm{TO}$ and the role Norway played in bringing Denmark and Iceland into the alliance was even more important. As the danger from the Soviet Union was seen as increasing, attitudes to the United States rather quickly became warmer. Yet the considerable opposition to NATO, which existed particularly within the Labor party, was at least in part related to a still lingering aloofness to the United States.

Expansion was quite as noticeable and less controversial on the cultural than on the political side. Reflecting the official bridgebuilding policy of the Norwegian government, in 1946 the University of Oslo established professorships in Russian and in American literature. The professorship in American literature was the first university position in Scandinavia devoted fully to the study of the United States. Sigmund Skard, who was appointed to this post, was to play a most important role in furthering NorwegianAmerican contacts. The generous Fulbright-Hays program increased the number of exchanges between the two countries sharply. The first American Fulbright professor came to Norway in 1949. The American Summer School in Oslo - created in 1947 brought many Americans to Norway. (Only in 1958 did it become the International Summer School.) The U.S. Information Service began its work in Norway after the war. In 1947-48 the American Field Service started its exchange program for high-school students between Norway and America. ${ }^{4}$

Before the Second World War Halvdan Koht, the brilliant and wide-ranging professor of history, had been the only Norwegian to write scholarly books on the United States, and his most important works related to American history had been published as early as 1910 and $1920 .^{5}$ The national bibliography of books, Norsk bokfortegnelse, for the period 1935-40 contained only 5-8 works by Norwegians dealing with America, depending on what we choose to include. For the period 1945-50 this increased to 
approximately $30 .^{6}$ Koht continued to write on the U.S., but he was now joined by several others, particularly by two other distinguished students of American affairs, Sigmund Skard and Ingrid Semmingsen. And the trickle of writings by journalists and politicians now increased to a modest stream.

These three leaders in the field of American studies were all generally pro-American, or, more accurately, strongly in favor of the American liberal tradition. In the first general history of the United States written by a Norwegian, Semmingsen in 1946 celebrated the reform presidents in the warmest of terms. This was how she chose to end her book En verdensmakt blir til (The Creation of a World Power): "When the message about Roosevelt's death reached us, we felt that we had lost a warm and faithful friend. His death was a personal loss to us all. And we know today that Franklin Delano Roosevelt's name will shine in history. George Washington and Abraham Lincoln belong to America. Franklin Delano Roosevelt's place is at their side. But Roosevelt does not belong only to America. He belongs to the world."7

Semmingsen's admiration for the reform presidents is joined by her interest in the history of the mass movements in the United States. Although periods of capitalist injustice are seen to exist, particularly the Gilded Age and the 1920s, the reform presidents are depicted as creating an alliance with the people to beat back this evil influence. The more reform the presidents undertake and the more opposition they meet from the greedy elements of big business, the greater they are generally seen as presidents. American history is often, but far from consistently, looked upon as unique compared to the European experience. Social mobility is seen as high, the American influence as democratic and, generally, but not always, benign. ${ }^{8}$

Semmingsen's work follows or belongs in the liberal American tradition. A certain dependence on this school of historians is noticeable. In 1946 this dependence was explained by both her political-cultural affinities to the American left and the limited original research she and other Norwegians had done in American history. On many points the influence of well-known U.S. textbooks by Henry Steele Commager and Samuel Morison and by Commager and Allan Nevins can be detected. Semmingsen had of course read Charles Beard's more radical interpretations of American history. Although Beardian influences can be found, she 
had on the whole been less influenced by his writings than by more moderate ones. ${ }^{9}$

Koht's America as seen through his important book The American Spirit in Europe. A Survey of Transatlantic Influences (1949) is similar to Semmingsen's. They admire many of the same persons and criticize some of the same things. That is as one would expect based both on their impulses from America and on their similar political views. Koht was one of the leaders of the Norwegian Labor party before the war, while Semmingsen, although not active in politics, shared the general Labor ideology.

Faithful to the title of his book, the scope of Koht's work is really breathtaking. So is his admiration for America, not only for the reform presidents and the popular movements, but even more for the vigor, ingenuity, and idealism he sees in the American heritage. Certainly greed, vulgarity, and materialism exist in America, but to a large extent they are seen as unavoidable features of the truly unique democracy of the United States. Similarly, the U.S. could be heavy-handed in international affairs, but it was still the only protector of democracy and small countries among the Great Powers. Most typical of all for Koht is his tremendous admiration for the inventions and economic growth of the United States. Occasionally he links all these elements together as when he writes that "Both phonograph and movie were a natural outgrowth of the democratic society of America, and they were powerful forces for the democratization of art in Europe."10

The expansion in admiration for and interest in America could be seen in many other studies as well. In 1946, 1947, and 1948 the journalist Per Vogt published three books on American presidents: Thomas Jefferson, Abraham Lincoln, and Franklin Roosevelt. The books came out under the shared title Freedom and Human Worth and were meant to explain the nature of democracy through personal biographies. The democratic idea was personified by Jefferson, the democratic ideal as a human type by Lincoln, and democratic rights in the world by Roosevelt. ${ }^{11}$ Norwegian-American Oliver Blekre Grimley wrote about the American presidents in a similar vein. ${ }^{12}$ Although these books should not be seen as hagiology, there could be no doubt about their positive attitude to the United States. They were important in one other respect as well. Even Norwegian conservatives, such as Vogt and to a lesser extent the leader of the Conservative party and also writer on American affairs, Carl Joachim Hambro, admired the strong lib- 
eral American presidents, certainly including Franklin Roosevelt, but not the conservative presidents. ${ }^{13}$

This would all seem to indicate a rather untroubled picture of the United States. Where, then, could the limitations on this expansion be found? Among scholars skepticism toward the United States was more noteworthy in Skard's works than in Semmingsen's and particularly than in Koht's, Sltard's own father-in-law. Even Skard celebrated the reform presidents and Roosevelt in particular and called them "our people" in America. As such they had inspired and assisted the Norwegian fight for freedom. His Amerikanske Problem (1949) is still an ambivalent book in many ways. True, in American history reform is seen as stronger than reaction, the people as stronger than big business. Yet, he describes the Democrats and the Republicans as both rather conservative, to a large extent dominated by big business. He pays tribute to the American people, but still regards it as complacent and uncritical of the basic capitalist ideology. While Koht celebrated the democratic nature of American culture, Skard sees the popular arts as dominated by commercialism and bland superficiality. Somewhat unexpectedly, the new professor of American literature complained that the number of American books translated into Norwegian had become so great that it represented a threat to Norwegian fiction. It was obvious that Skard was having the greatest of difficulties in reconciling the parts he liked with those parts of America he clearly disliked. ${ }^{\mathbf{1 4}}$

The limitations in the Norwegian admiration for America were probably most clearly underlined by repeated references to Norway's and Scandinavia's middle road. Again, this conclusion was most explicit in Skard's Amerikanske Problem. He stressed that the Soviet Union did not represent Norway's road, but neither did the United States. Conditions in Norway and America were different and "Our line is in the middle, politically and socially, economically and culturally." Although Western Europe needed support from the United States and although Skard did support Norwegian membership in NATO, he still clearly wanted to limit the American influence. ${ }^{15}$

The limitation aspect could be found even with Koht. While Skard wanted to defend Norway from Great Power influence, Koht was more ambitious. He wanted the collectivism of the Soviet Union and the individual enterprise of the United States to come together and "for the high development of both ideas, I 
venture to instance my own country, Norway." Thus, Norway, not America, really represented the synthesis of the future, despite Koht's great admiration for the United States. ${ }^{16}$

\section{$I I=1949$-approximately 1965 : kinzitations under pressure}

In 1949 Norway became a member of the NATO alliance. This meant that the United States quickly replaced Britain as Norway's primary guarantee power. Most of Norway's military equipment now came from the other side of the Atlantic; Norwegian officers were trained there; and both deterrence in peace time and war fighting capability would be provided by the United States. Foreign investment increased rapidly so that in 1368 almost 30 per cent of the foreign capital in Norway was American.

Yet, important reservations had been tied to the NATO membership. The Norwegian government had made it clear that it could not accept foreign bases on Norwegian soil. From this it followed that it could not permit the stationing of atomic weapons either. In addition, the Labor government was opposed to a widening of the NATO alliance, particularly in geographic terms. Finally, Norwegian defense budgets were still fairly low by international standards.

On all these fronts modifications would take place in the 1950s. The defense budget doubled in constant prices from 1950 to 1954 . Membership in the NATO alliance came to include not only Italy, but also Greece, Turkey, and West Germany. Efforts were made to modify Norway's base and atomic policies, although in the end the modifications became rather small. ${ }^{17}$ It was obvious that the many limitations from the 1945-49 period were under considerable pressure in the 1950s and early 1960s.

In the cultural sphere a similar expansion took place. In many fields of academic work it was considered almost a sine qua non to have spent some time in America. By 196960 per cent of Norwegian social scientists and 50 per cent of natural scientists had spent at least half a year in the United States. ${ }^{18}$ Among the leaders in these fields the percentages were even higher. American films made up 50 to 60 per cent of all imports. The market was flooded by American music, by American and American-inspired magazines, and the number of American books translated into Norwegian rose steeply. By 1962 Kemingway had appeared in 24 Norwegian editions and total sales of his books ran at 270,000, 
almost the same as in Sweden whose population is more than twice that of Norway. ${ }^{19}$

Public confidence in the United States was also rapidly growing. Only a small minority - 13 per cent - continued to believe that the United States represented a threat to world peace, although in the early 1960 s this percentage was higher in Norway than in for instance Britain, France, Denmark and Switzerland. In 1963, 66 per cent answered that they had trust in the United States as a friend and an ally. That was only one percent lower than the figure for Britain. Not more than 22 per cent had such faith in France and Germany. ${ }^{20}$

How then do developments within American studies fit into this general political-cultural framework? Fairly well, although there was no perfect fit between scholarly research and political climate, as could be expected in a democratic society. In 19451949 the tone of scholarly research had been surprisingly positive to the United States. In the years from 1949 to 1965 many elements would accord well with the new over-all climate, but some research could not easily be classified within this framework at all.

Generally, then, this period represented years of expansion: the number of persons involved in American studies increased, new organizations were founded and, most important, much of the research produced was based on views quite friendly to the United States.

Sigmund Skard was undoubtedly the leading person in Norway on the organizational side. With seemingly indefatigable enthusiasm he fought for a larger role for American studies, primarily in Norway but also in the rest of Europe. In 1954 he organized the European Association for American Studies and edited its news-letter for three years. When the Nordic Association for American Studies was founded in 1959, he became quite active there. In 1957, after ten years of bitter struggle, he was finally able to make U.S. literature and civilization almost, but not quite, equal to the corresponding British parts within the English study at the University of Oslo.

With his good international connections and his administrative talent, Skard was able to secure substantial financial assistance for research related to the United States. In 1963 a full professorship in American history was established and Ingrid Semmingsen was made Norway's first professor of American history. Fulbright 
professors came to Norway on a regular basis. The reforms in the Norwegian university system in the late 1950 s, with the introduction of basic one-year courses, in time led to several new lectureships in American literature and a slight strengthening also of the teaching of American civilization.21

In his fight for American studies in Norway, Skard felt the need to find out what other countries had done. He hoped to prove that this was indeed a serious field of research with a strong tradition in many countries. He visited universities in 12 countries and circulated questionnaires to about 600 scholars at 160 universities and out of this came a detailed presentation of research involving the United States in almost every European country. The result was his massive two-volume American Studies in Europe. Their History and Present Organization. ${ }^{22}$

In the 1950s Skard's emphasis on the Norwegian middle road was to disappear entirely, and when later it surfaced again it came back in much modified form. His American Studies in Europe was based on a very friendly attitude to the United States. In the more ideological parts of his work, he would write that the Soviet danger "forced the Western nations to close their ranks under American leadership. And behind the military and economic cooperation the Europeans felt the need to join their forces even intellectually, by a more systematic effort to understand the common cultural foundations of the West, including the United States."23 Skard seems fairly close to the truth when, twenty years later, he wrote that "looking back at my book now, it appears to me as a typical document of the Cold War, where, for understandable reasons, the line of demarcation between black and white was drawn more sharply than it would in the 1970s." 24

Skard spent the academic year 1957-58 at the University of Indiana at Bloomington. This was his first long-term visit to the United States in ten years and was to bring back some of his old doubts about America. Apparently he was influenced more by cultural developments than by political ones. Suburban materialism and the shallowness of American mass media appeared to him as particularly negative. He also became impressed by Max Lerner's occasionally pessimistic America as a Civilization. The result was that when his American Studies was published in a revised and abbreviated form in 1961 as The American Myth and the European Mind most of the more stridently ideological passages had been removed. ${ }^{25}$ 
The ramifications of the Cold War could be noticed in many other writings as well. C.J. Hambro published an extremely admiring essay on General Marshall. ${ }^{26}$ Even more black-and-white were the books and pamphlets put out by the U.S. Information Service. Among other things, here it would be announced that although the welfare of poor people might have been neglected in the past, this was not true any more. The "so-called" class struggle of Europe had allegedly also lost its meaning in the United States. ${ }^{27}$

A toned-down version of this rather untroubled optimism was produced by Norwegian-American Sverre Norborg, who before he emigrated to the United States had written the first Ph.D. dissertation in Norway on an American topic, his 1934 work on the American philosopher Josiah Royce. His book from 1958 Det nye Amerika. Hovedstromninger $i$ amerikansk kultur og verdenspolitikk (The New America. Main Currents in American Culture and World Policies) was based on lectures given at Oslo University and was very friendly to the United States. There might still be a few poor people in the United States, but on the other hand it was only a question of time before the four-day work week would be generally adopted. America had proved the irrelevance of Marxist-inspired research, since the people's capitalism of the United States had solved all basic economic problems. In a country where "blacks drive new Cadillacs and school kids move around in Thunderbirds", the car had no meaning any longer as a status symbol. If anything should be criticized in American foreign policy, it would have to be FDR's personal diplomacy and his lack of understanding for the ruthlessness of Communism. ${ }^{28}$ So, although Norborg was rather critical on this point, his criticism came from the right and not from the left.

In the late 1950s Aschehoug's Verdenshistorie was published in 8 volumes. Considerable space was devoted to the history of the United States. Norway's most internationally minded historians contributed and the tone was generally sober and uncontroversial. This was also the case with the longest contribution on American history, Arne Ording's chapters on the years from 1920 to 1940. Ording's presentation was based on no over-all view, but was closely written and was full of iniormation. Again, the influence of the liberal historians in America was perceptible, although his portrait of Franklin Roosevelt was actually less marked by hero worship than had been the case in the writings of the 1940s. 
However, in its brief sections on the post-war period, even Aschehoug's Verdenshistorie bordered on ideological advocacy. Here the Soviet Union was seen as a strongly expansionist power with which the United States had desired to cooperate after the war. Only when its efforts had proved futile beyond any reasonable hope, did the United States embark upon a more active foreign policy, in the form of containment of Soviet Communist expansion. Still, since parts of the analysis were based rather closely on William McNeill's America, Britain, and Russia. Their Co-operation and Conflict this was moderate, rather than extreme Cold War orthodoxy. ${ }^{29}$

In the Swedish 21 volume series Grimberg's world history, less space was devoted to the United States. This was the case also in the final volume covering the inter-war period written by Norwegian journalist Christian Arthur Richardt Christensen. Little more need be said than that it continued the longstanding Norwegian admiration for Franklin D. Roosevelt. ${ }^{30}$

To sum up, the change in the 1950 s toward even more favorable attitudes to the United States was most clearly witnessed in Skard's writings. The emphasis on Norway's middle road disappeared. There was little direct criticism of the United States in this period. This was all the more noteworthy because of the conservative nature of America in the 1950s compared to the 40s. Historians on the political left chose to write about other topics. Jens Arup Seip, perhaps Norway's most distinguished historian after the Second World War, did spend the academic year 1948-49 in America, but nothing came out of his stay in the form of writings on American history.

Some criticism could still be found, in official as in scholarly circles. Because of the strong scholarly sympathy for the U.S. even in the 1940s, the transition from the 1940s to the 1950s was somewhat smaller in this field than in the over-all NorwegianAmerican relationship. Skard was negatively influenced not only by cultural developments in the United States, but also by the basic conservatism of the $1950 \mathrm{~s}$, particularly by the McCarthyism of the early part of the decade. Yet, this attitude showed more in private thoughts than in public comments on his part. ${ }^{31}$ In his Freedom of Speech in the West. A Comparative Sludy o Public Law in France, the United States and Germany, Professor Frede Castberg was clearly skeptical of the limitations imposed upon free speech in the United States, although this skepticism was expressed in restrained terms. ${ }^{32}$ 
All who touched on the topic agreed that the American treatment of blacks represented a stain on American history. Norborg was also quite explicit on this point, but it was perhaps symptomatic of the 1950s that so little was actually written about the racial situation in the United States. ${ }^{33}$

With the advent of the Kennedy administration in 1961, celebration of the United States in some ways reached its maximum. The change from the seemingly lethargic style of Eisenhower was dramatic and accorded well with Norwegian values. ${ }^{34}$ Kennedy was certainly admired by most observers to the left and in the political center. What was more surprising was that even conservative writers shared this basic preference for Kennedy over Eisenhower, and Nixon for that matter. This was noticeable from parts of Arne Bonde's U.S.A. Plus/Minus, although this book was written as late as $1968 .^{35}$ In the last analysis this attitude was probably due to the fact that by international standards even Norwegian conservatives were rather liberal.

Halvdan Koht, the pioneer of American studies in Norway, died in 1965. Shortly before his death he wrote an article in the journal Syn og Segn praising the achievements of modern technology, much of it American in origin. The nuclear merchant vessel "Savannah" was only the latest example. ${ }^{36}$ This provided a contrast with the thinking of his son-in-law, Skard, who generally felt far removed from the wonders of modern technology. As Skard himself was later to recognize, his reaction to this side of America was very much "the reaction of a Protestant farmer visiting one of the great modern cities." ${ }^{37}$

III : Approx. 1965-mid 1970s: The contraction of the Norwegian-American relationship

Although no definite turning point exists, there can be no doubt that in the late 1960s and early 1970s Norwegian attitudes toward the United States became much more negative than they had been at any earlier time in the post-war period.

If we are to point to one specific factor which brought this about, it would have to be the Vietnam war. Vietnam led to sharply critical appraisals of the United States not only from persons on the left; even many who considered themselves friendly to the United States took part in demonstrations against the American conduct of the war. Norway's largest paper and the main paper associated with the Conservative party, Aftenposien, 
wrote in December 1972, during the stepped-up bombing of Hanoi, that "In these days it is not easy to be among the friends of the USA." 38

But Vietnam was not the only issue disturbing NorwegianAmerican relations in this period. As one of the most promising young Labor politicians, Einar Farde, would write in 1969, Anierica "has come to stand for actions and ideals which ought not to be ours." 39 On the foreign front the American support to the colonels in Greece and Washington's destabilization policy toward Allende's Chile were to have negative repercussions in Norway. On the domestic front Lyndon Johnson was for a short time seen as a possible new member of the group of reform presidents so popular in Norway, but the Vietnam war soon overshadowed the substantial reforms he achieved in the domestic arena. The assassinations of John F. Kennedy in 1963 and of Robert Kennedy and Martin Luther King in 1968 horrified all Norwegians, and many thought such violence said something about American society in general. Race riots took away the luster of the civil rights reforms. While poverty had apparently not existed in the United States of the $1950 \mathrm{~s}$, it was rediscovered in the 1960s. To top this off, the Watergate crisis received intensive coverage in Norway. Dislike of Nixon and his staff was near universal and only a conservative minority argued that the role of the press (actually The Washington Post and The New York Times) could be seen as a compensating victory for democracy in the United States. ${ }^{40}$

The new attitude to the United States was also striking in the cultural field. Condemnations of America became as routine as they had been rare in the 1950s. Interest in scholarly visits to and exchanges with the United States declined significantly.

The more negative view of the United States could be found in academic writings as well. In this period Skard published important works on the image of the United States in Europe in general and in Norway in particular. Many of his findings were actually based on Koht's The American Spirit in Europe from 1949. Like Koht, in his treatment of images of the past, Skard would still point to the United States as the symbol of democracy, the bulwark against political oppression, the innovator, the producer of mass affluence, even as an example of "unconscious socialism". Despite the Gilded Age and the 1920s, these basic images lingered on well into the post-war period in Norway as well as in the rest of Europe. ${ }^{41}$ 
But as early as in 1968 Skard would refer to "the doubts about U.S. foreign policy today, even among its staunchest friends .."42 In his massive compilation from 1976 of Norwegian attitudes to the United States USA i norsk historie (abbreviated American edition: The United States in Norwegian History), it was obvious. that Skard not only referred to the images of others, but also had himself lost faith in contemporary America, despite the tremendous contributions of the United States in the past. Only conservatives could admire the U.S. any more. Yet, even many of them were "'more than open to the dark aspects of present-day America, both in its internal and foreign policy, and often point to the same frightening features that are being underscored on the radical side." 43

Skard was active in many fields. In an article from the mid 1960s he argued, although with reservations, for the integration of the many disciplines concerned with America. ${ }^{44}$ His specialty of teaching was really American literature, although his major publications in this field were relatively few. His survey of American literature written in 1965 for Time-Life had been fairly pessimistic, expressing his worries about the quality of life in general and the state of recent American literature in particular. ${ }^{45} \mathrm{His}$ writings in the early 1970s on U.S. literary history are conventional and less marked by his growing disillusionment, but they cover only the period from 1800 to $1890 .^{46}$

His changed attitude was of course related to the responses most Norwegians had to the events unfolding in the United States in these years. Still, Skard was rather slow in reacting to the Vietnam war, and the time he spent in the United States in 1966 was in personal ways his most happy in that country. The change was probably more influenced by his growing hostility to the consumer culture and by a new nationalism in Norway. The new counter-culture which inspired many opponents of the official America, was no alternative for Skard, Few could be further removed from the life styles associated with this phenomenon. In the early '70s he also felt that new oil finds were making Norway "part of the great capitalist game of power." Finally, his skepticism toward the United States, which was now much stronger than it had been in 1945-49, was undoubtedly also related to a pessimism not only about the U.S.A., but also about the world and human existence in general. ${ }^{47}$

Skard's re-evaluation of the United States was not lightly under- 
taken, for he had invested much of his life in American studies and it was obvious that he felt a strong need to be enthusiastic about the objects he studied. He was not a man to study persons or cultures he disliked.

In 1972 Semmingsen published the second edition of her En verdensmakt blir til (The Creation of a World Power). She was reluctant to make major revisions in the text compared to what she had written in 1946, but those which were made tell us something about the extent to which her views on the United States had changed. Her celebration of the reform presidents was dramatically toned down, although some still remained. The reappraisal among some American historians of conservative arch-villain Herbert Hoover had also led to the picture of him being less negative than in 1946. Economic considerations were somewhat, but not really much more important to Semmingsen in 1972 than in 1946.

Her treatment of the post-war period was conventionally liberal. A certain sympathy for Stevenson was noticeable while Eisenhower was seen as a passive president of good will. Her criticism of American foreign policy in the 1950s was restrained but still there, while the Cuban missile crisis was, as expected, portrayed as Kennedy's finest hour. Mild disapproval of U.S. policies in Vietnam, toward China, and of American anti-Communism in general can be found. Her more skeptical view was clearly expressed toward the end of the book when she suggested that hope for the future lay in the idealism and humanitarianism of religious groups and of' the protest movement, not in official policies. ${ }^{48}$

In 1973 the respectable journal Internasjonal Politikk put out a special issue on the United States written by Norwegian specialists in the field. The focus of the issue was on the domestic scene and the pessimistic-critical tone was evident in almost every article. The long-standing admiration for the strong presidents could still be found, but the problem, as it existed also for liberals in America, was how to react when conservatives became strong presidents. Per Seyersted, a leading authority on American fiction, suggested that with Nixon reality had become even more fantastic than fiction. And this was before the Watergate crisis had really climaxed. A certain implicit disillusionment even with Kennedy was noticeable. Torbjørn Sirevåg stressed the domination of conservative forces and "it makes you wonder about the value of using different party names in presidential elections in America 
of the 1970s." Other specialists complained about the sorry state of the American melting pot, the spreading decay of the big cities, the threat of pollution. ${ }^{49}$

In the years from 1970 to 1975 several works were also written about the situation of blacks in the United States. These were non-chronological and often journalistic and therefore fall outside the scope of this essay, but they all explicitly or implicitly illustrated Norwegian sympathies with the cause of blacks in America. The admiration for Martin Luther King, Jr. was very pronounced and near universal in Norway, particularly after he had received the Nobel peace prize in 1964. Although important changes were recognized to have taken place in the civil rights area in the 1960s, the emphasis on the treatment of blacks had to tarnish the image of America..$^{50}$

The criticism of the United States was widespread and, although it had many sources, it was to a large extent a product of the Vietnam war. In January 1973 all tenured teachers in the fields of American literature, civilization, and history signed a protest against the American conduct of the war. The protest noted that while American idealism had come to represent much of the best in the western cultural tradition, "this idealism has always fought a hard battle against selfish interests motivated by the search for profits and the desire for an extended sphere of power for the United States." The warfare in Vietnam and the American support to many reactionary dictatorships was "expressive of a policy which has made the United States a travesty of itself as the nation which once captured the aspirations of the world." 51

The relatively few writings of Norwegian social scientists which touch upon the United States have not been included here, since they lack a chronological dimension. The most influential of these scientists were undoubtedly Stein Rokkan and Johan Galtung. Rokkan's orientation was generally empirical and comparative, and it is difficult to say anything specific about his views on the United States. Galtung's writings were quite different, generally more speculative and quite political in their approach. His denunciation of the United States was particularly strong during the Vietnam war. America was "a perilous country, for itself and for its neighbors" and was seen as conducting an old-fashioned imperialist policy. ${ }^{52}$

Even many conservatives became somewhat negative to the 
U.S. and skeptical of its future. In 1969 the Conservative Student Association in Oslo had devoted a special issue of its journal Minerva to the United States. The beginning of the lead-off editorial clearly illustrated the new tone: "Is the United States today a "sick" society? The question is raised ever more frequently - and with good reason. For the news can tell about a society in inner conflict, ravaged by serious crises." Then the editorial went on to list some of the challenges the United States faced: the distribution of affluence had to be made less uneven, pollution combated, the race question solved also on the personal level. But the basic problem was one of identity. Old methods and objectives had shown their shortcomings, and new ones could not easily be found. The most hopeful sign was that the problems were openly discussed within the political system instead of leading to extremist measures. ${ }^{53}$

With even many conservatives criticizing the United States and its foreign and domestic policies, the end of the 1960s-early 1970s undoubtedly represented a decline in the prestige of the United States in Norway.

This picture was not quite uniform, however. On the organizational side and in the total number of scholarly publications dealing with America, continued expansion took place. In fact, this was the period with the most rapid growth in university positions in American studies at the universities of Oslo, Bergen, Trondheim, and the new one in Tromsø in Northern Norway. Skard has argued that in propo tion to the population, no European country came to have more people teaching American literature and history than Norway. In 1976 four full professors, two associate professors, 14 assistant professors and one research assistant were working at Norwegian regional colleges and universities within these fields. More than 200 theses had been written in American studies, roughly 160 in Oslo, 25 in Bergen, 20 in Trondheim. ${ }^{54}$

Most of this expansion occurred on the literature side and therefore falls outside the scope of this essay. Let me just mention that important studies were written on Kate Chopin by Per Seyersted; on Howells and James by Jan W. Dietrichson; on Hart Crane by Helge Normann Nilsen; on Orestes Brownson by Per Sveino; on T.S. Eliot by Kristian Smidt and on James Fenimore Cooper by Orm $\emptyset$ verland. These and other Norwegians contributed to the four volumes of Americana Norvegica put out in the years from 1966 to 1973.55 
In 1975-76 two events coincided which led to new publications on the United States, the 150th anniversary of the first emigration from Norway and the American bicentennial. The most important of the emigration works was Semmingsen's Drom og dåd (English translation Norway to America). ${ }^{56}$

For the bicentennial Bjørn Jensen edited a collection of 25 essays on the United States under the title Mote med Amerika. 25 nordmenn oppfatter amerikansk historie og nåtid. (Meeting with America. 25 Norwegians Interpret the American Past and Present). ${ }^{57}$ It could have been expected that such an occasion would have led to an outburst of old clichés, and to some extent that happened. Haakon Lie praised American labor unions as the strongest in the free world. The efficiency of American business was applauded, and so were the few quality newspapers America had. The celebration of FDR was nothing new. Somewhat more original, supporters of the counter-culture lauded various aspects of American life: its contributions to modern feminism, pop music, the youth and the underground cultures. ${ }^{58}$

Still, the basic tone was fairly pessimistic. The editor wrote that perhaps the United States had a special need to celebrate its bicentennial because the American search for identity had met with such serious setbacks in the last years. Semmingsen pointed out that although American democratic ideals had inspired the world, an equal number of cases could be found where the United States had violated the principles of freedom and equality. Dorothy Burton Skårdal thought Americans had now finally been forced to recognize that class differences in the United States were rather the same as in Western Europe. The racial situation had been considerably improved, it was noted, but America had still a long way to go before the problem could be considered solved. ${ }^{59}$

Yet one observer noted that although Watergate and Vietnam represented the nadir of the United States, signs of improvement could be detected. ${ }^{60}$ This leads us to our final period, the very last years.

\section{IV: Mid 1970s-1980 = A new balance}

Although it is somewhat reckless, I would argue that the years from the mid 1970s to 1980 have been different from the period from the mid 1960s to the mid 70s. At least in some ways relations between the United States and Norway became closer, although 
they far from approached the relative harmony of the period from 1949 to 1965 . The new expansion was particularly obvious in the military area, but was noticeable in economic and cultural affairs as well.

To some extent the expansion was the result of the passage of time and the resolution of problems which had had a negative impact on the American-Norwegian relationship. The Vietnam war came to a close. Watergate became a thing of the past. Jimmy Carter represented an improvement on Richard Nixon, most Norwegians thought.

The Soviet build-up of the fleet on the Kola peninsula, the faltering of detente, and bilateral Soviet-Norwegian problems in the North were to change Norwegian defense planning. The American security guarantee was recognized by the major parties as more important again, although this recognition was less clearcut on the public level.

On the economic front, Norway's role as an oil and gas producing country strengthened the American presence in Norway. Popular attitudes toward the U.S. also improved as compared with the Vietnam-Watergate period. In September 197822 per cent of the Norwegian public considered Norwegian-American relations quite good, while 59 per cent considered them fairly good. Only 2 per cent responded that they were either fairly or very poor. These percentages remained virtually unchanged in a similar poll from May, 1980. At the same time, however, a sizeable group thought Norway too dependent on the United States and an even larger number - 45 per cent - agreed that American influence on Norwegian life was too strong. ${ }^{61}$ The 1950 s were definitely gone.

The 1970s came to represent a generational change in the study of the United States in Norway. Skard retired as university professor in 1973, Semmingsen four years later. Although they both continued to work actively in their fields, their influence would gradually be reduced. As we have seen, Skard in particular became disillusioned with the United States and after he had finished his USA $\mathrm{i}$ norsk historie, he turned to the writing of his memoirs. ${ }^{62}$

Much of the activity in American studies would be on the literature side and thus falls outside the scope of this essay. Among

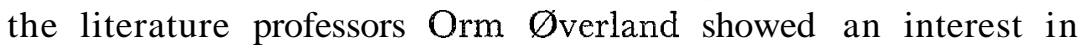
the American role in the world also outside of literature. Per Seyersted came to do work on American Indian literature and on 
the author Leslie Marmon Silko in particular, which also involved some study of Indian culture in general. Also pointing to a new interest in the Indians, among the civilization teachers Ole Moen wrote an analysis of the works of Red-country author Frederick Manfred. ${ }^{63}$

Within history and civilization the new names would be Torbjørn Sirevåg, Dorothy Burton Skårdal and Geir Lundestad and, less exclusively preoccupied with the United States, Welge Pharo and Olav Riste. The only full professorship in American civilization was at the new University of Tromsø and it would be filled first by Sirevåg and, after he left academic life in 1978, by Lundestad. After Semmingsen's retirement the chair which she had held in American history at the University of Oslo, was taken over by Edgeir Benum. Benum's background was in Norwegian history, but he maintained some of the position's association with American history.

The transition to a new generation would be gradual as the older generation continued their work and as most of the younger people had published books and articles before 1975-76. Nevertheless, a change in topics was clearly noticeable and the most important of the new works would be published in the last half of the 1970s.

Skard's major fields had been the organization of American studies, the image of the United States, and U.S. literary history. These were not really followed up by the new generation. ${ }^{64}$ Emigration research, which will not be dealt with in this essay, continued, but in part in a new form. Theses would still be written in the established Semmingsen tradition, but much of the work in this field would now be done under Skårdal's supervision within Norwegian-American literary and to a lesser extent social history.

The new areas would be American domestic politics and even more U.S. foreign policy, both almost exclusively concentrating on the 1940s. Several explanations can be found for this change of focus. A surge of interest had taken place in recent history in general, and the $1940 \mathrm{~s}$ was the last decade from which most of the source material on the American side was now available. In foreign policy the underlying question that stimulated much of the new research was the origins of the Cold War. Since Russian was a difficult language and little material was available in Moscow, a concentration on the American side was natural. Finally, a certain admiration for both Roosevelt and Truman could be 
noticed in the writings on their periods. To the new generation these years were more to their liking than later decades. The image of America which emerged could be said to be more positive than that of the late 1960s and early 1970s, although it was far from as untroubled as that of the 1950s and early '60s. But, as we shall see, the change in scholarly attitudes was less dramatic now than between the previous periods.

Torbjørn Sirevåg has written numerous articles on Franklin D. Roosevelt and the Roosevelt period. His most important work is his doctoral dissertation Eclipse of the New Deal: The Fall of Vice President Wallace, 1940-1944. ${ }^{65}$ The dissertation is actually much more than a study of Wallace's fall. The entire war-time Washington scene is presented. Sirevåg goes deeply into the political and to some extent the personal lives of Roosevelt, Wallace, and Secretary of Commerce Jesse Jones. In the more limited question of why Wallace was not renominated as Vice President in 1944, Sirevåg argues that this was FDR's personal decision, based at least as much on foreign as on domestic policy considerations, and more the result of tactical evaluations than of policy differences between the two protagonists.

On the foreign policy side, some scholarly writings had been published in the 1950s, primarily in parts of Aschehoug's Verdenshistorie. Then, in the mid 60s, Olav Riste had included new material also on the American side in his The Neutral Ally. Norway's Relations With Belligerent Powers in the First World War. ${ }^{66}$

The surge in activity would come in the 1970s. The first product of the new wave was Pharo's thesis from 1970 Mal og midler $i$ amerikansk utenrikspolitikk, februar-juli 1945. En kritisk vurdering av revisjonistenes syn på ameriknnsk utenrikspolitikk (Objectives and Means in American Foreign Policy, February-July 1945. A Critical Appraisal of the Revisionist View on American Foreign Policy). ${ }^{67}$

The thesis was the first comprehensive presentation in Norway of the international debate on the origins of the Cold War. As the subtitle revealed, it was largely critical of the left-wing, revisionist position. In 1972 Pharo edited an anthology where the most prominent American traditionalist and revisionist historians were represented, USA og den kalde krigen (The U.S.A. and the Cold War). ${ }^{68}$

In 1973 Riste published his article "An Idea and a Myth: Roosevelt's Free Port Scheme for North Norway" linking the study of American and Norwegian foreign policy. ${ }^{69}$ In 1973 and 
1979 he summed up his research on Norway in international' relations during the Second World War in Londonregjeringa. Norge $i$ krigsalliansen 1940-1945, I and $I I$ (The Government in London. Norway in the War-Time Alliance 1940/1945), ${ }^{70}$ a painstaking study of the topic indicated in the title. Riste's work focused much more closely on British than on American material, particularly on the political side. This was at least in part to be expected since the British role was the most important.

Lundestad has written two books on American foreign policy, The American Non-Policy towards Eastern Europe 1943-1947 (1975, reprinted 1978) and America, Scandinavia, and the Cold War, 1945$1949(1980) .{ }^{71}$ Both books were intended as contributions to the American debate on U.S. foreign policy in the early Cold War period, and although they tried to transcend the traditionalistrevisionist split, many would argue that they were closer to the traditionalist than to the revisionist side.

The revisionists' emphasis on the United States as the guilty party to the Cold War was rejected. The question of blame was seen as moral-political and not one for historians to decide. The near exclusive preoccupation of the revisionists with economic factors in American foreign policy was also attacked. Strategic, domestic, economic, and other factors were all seen as important, the relationship between them changing from time to time and from place to place.

Washington's policy toward Eastern Europe was described as: a non-policy, an uneasy mixture of ambition and strength on the one hand and local weakness and concentration on areas outside Eastern Europe on the other. Similarly, the United States was seen as having had only marginal interest in Scandinavia until the fall of 1947 and even after that time American policy-makers often showed considerable flexibility in their desires to fit Norway, Sweden, and Denmark into a Western alliance. On the domestic side, only very limited attempts were made to modify the policies of the Scandinavian Social Democratic governments.

Although traces of revisionism could certainly be found - again there was no going back to the 1950s - this wave of foreign policy writings illustrated the new and somewhat improved over-all climate between the United States and Norway. But it should be repeated that it is difficultto separate this period clearly from the preceding one. In some ways it could even be argued that the basic tone of moderation and skepticism toward at least the more extreme 
forms of American historical revisionism had been set as early as 1969 in Riste's review of Towards a New Past. Dissenting Essays in American History, the important collection of essays by New Left historians on different aspects of U.S. history. ${ }^{72}$ Thus, in academic writings on American foreign policy moderation prevailed even in the period of great strain in Norwegian-American relations. As we have seen, the transition from the third to the fourth period was more marked in other fields and in the generational change.

In recent years American citizens connected with Norway have published writings on America in Norway. John Ausland, the No. 2 man in the American Embassy in Oslo in the years from 1969 to 1973, has written an interesting book about the views and role of the embassy in that period..$^{73} \mathrm{His}$ account of the strain in diplomatic relations after Norway's recognition of North Vietnam in 1971 caused a minor stir in the Norwegian press when the book was issued. In 1980 Elen C. Singh's (née Sakshaug) The Spitsbergen (Svalbard) Question : United States Foreign Policy, 1907-1935 came out. The book was a slightly revised dissertation from the University of Denver and offered a descriptive analysis of American policies toward an area of marginal interest to Washington. Her conclusion was similar to that presented in Norwegian Cold War studies in that economic interests were shown to have had some influence on U.S. policies, but far from dominated the shaping of these policies. ${ }^{74}$

\section{$V$ : Conclusion}

This essay has argued that scholarly writings on the United States have followed the basic trends of the over-all Norwegian-American relationship. Thus, the 1945-1949 period was one of westwardleaning bridge building in official diplomacy as well as in academic publications. Despite the admiration for the United States in many fields, the value of the Norwegian and Scandinavian middle road was emphasized by politicians and scholars alike.

From 1949 to 1965 the American-Norwegian relationship was generally close and the limitations which had existed on the American influence in Norway came under pressure. This, again, was reflected in the writings on the United States. Even Skard, who had been the most skeptical of the leading Arnericanists in 
Norway, abandoned the middle road and instead came to adhere to the basic split between East and West, between freedom and totalitarianism.

From the mid 1960s to the mid 1970s the Norwegian-American climate turned rather cold. Criticism of the United States was rampant, in political as in academic circles. Perhaps most surprising was the extent to which even conservatives shared the more critical attitude toward the United States.

From the mid 1970s the tone became somewhat softer again. Norwegian-American military cooperation was strengthened, economic and cultural contacts improved. The warmth of the 1950s and early 1960s could not be brought back, but as the political relationship improved scholarly publications became more detached and less critical of developments in the United States.

Of course not everything would fit into such a rather crude picture of Norwegian writings on the United States. Thus, emigration, which has consistently constituted one of the main areas of Norwegian research related to America, can not easily be fitted into this pattern. The same was true of the organizational growth of American studies. The greatest growth did actually take place in the period when the official relationship was the coolest. This had to do with the student explosion of the 1960s, which made it necessary to create many new positions and even entirely new universities and colleges.

Other modifications should certainly also be made. In 1945-1949 the admiration of leading Americanists Koht, Semmingsen, and to a lesser extent Skard for America and the American reform presidents in general and FDR in particular was greater than that found among Norwegian politicians. Because of this, the break from this period to the next of the friendly 1950s and early 1960s was clearly less marked in the scholarly than in the political world. The same was true for the relationship between official policy and academic writings in the third and fourth periods. Thus, the wave of writings on American foreign policy, which was almost without exception critical of left-wing revisionism, really started around 1970 , in the period that marked the nadir of the official NorwegianAmerican relationship in the post-war years. The change from the third to the fourth period was therefore more marked in other fields and also in the generational change.

The relative unanimity of scholarly writings in the different periods was another striking feature of Norwegian research on the United 
States. Of course there was never complete agreement. As we have seen, in 1945-1949 Koht was more positive to the United States than were Semmingsen and particularly Skard. Even in the late 1960s- early 1970s a few writers would continue to write almost in the mood of the 1950s and early 60s, although they were admittedly marginal within the Norwegian academic world. ${ }^{\mathbf{7 5}}$

Many explanations can be offered for this relative consensus. Few persons were involved in research on American history and civilization. Many of them held similar political views. Almost all of the leading Americanists in Norway sympathized with the Labor party. But even conservatives admired the reform presidents and many of them too would be skeptical toward the United States of the Vietnam-Watergate period. This only serves to underline that in an international perspective ideological and party differences are small in Norway. Finally, it appears that certain persons were more easily attracted than others to the study of America. Those more critical of the United States, such as Seip, worked on other subjects. Although the cause and effect relationship is complex, it may be that much contact with America led to a basic sympathy for that country. Nevertheless, the Labor affiliation of most Americanists indicated that this sympathy had its clear limits.

One could ask whether scholarly writings had any influence on official policies, since they were so similar in tone. The answer would have to be that this influence was insignificant. Of the writers mentioned in this essay, only Haakon Lie, C.J. Hambro, and to a lesser extent Arne Ording carried significant political weight, but Lie and Hambro were politicians, and marginal as Arnericanists. Robt, foreign minister from 1935 to 1940, was not really active in politics after the Second World War. Perhaps the question makes it necessary to stress that there was not much influence from politics to academia either. It was primarily a question of shared perceptions among the political and academic elites interested in the United States, not of scholars following the turns of official policies.

The topics which Norwegian Americanists have studied have to a large extent been those one would naturally have expected. By far the most work has been done on the bilateral Norwegian-American relationship in the widest possible interpretation of that term, from Norse explorations of Vinland - omitted here - through emigration research to the American image in Norway and U.S.Norwegian diplomacy.

But naturally, some publications have broken with the trodden 
path. One general history of the United States has been written, and aspects both of American diplomacy and politics which have nothing to do with Norway or even with Scandinavia, have been dealt with. However, even most of these have generally had at least one "expected" dimension in that they have been quite sympathetic to the reform presidents and to the Roosevelt period in particular. The most surprising thing is that so little of substantial academic work has been done on the situation of blacks in the United States, a topic that has been very popular with both the press and the general public. At the academic level more of substance has probably been written about Indians than about blacks.

Yet, American studies in Norway have attracted some strong personalities who were not content to limit themselves to the more obvious topics. Halvdan Koht would write not primarily about the American influence in Norway, but about the American influence in Europe. Sigmund Skard would write about the development of American studies in Norway, but, again, this would be in a wider European framework. To these two and to Ingrid Semmingsen American studies in Norway and perhaps even elsewhere too owe much.

\section{NOTES}

1 Pioneering work in the field of cultural international relations has been done by Akira Irye. See for instance his "Culture and Power: International Relations as Intercultural Relations", Diplomatic History, Wilmington, $3: 2$, pp. 115-28; See also his Mutual Images. Essays in American-Japanese Relations. Cambridge, Mass., 1975, pp. 1-23 in particular.

2 These terms I have earlier used in my America, Scandinavia, and the Cold War, 1945-1949. New York, 1980. See pp. 36-37 in particular.

3 The development of the American-Norwegian relationship is covered in my America, Scandinavia, and the Cold War. For the poll mentioned, see Bjern Alstad, ed., Norske meninger (Norwegian Opinions), I. Oslo, 1969, pp. 89-90.

4 Letter from the American Field Service, Norway to Geir Lundestad, September 17, 1981. For an article on the effects of the AFS program on the students involved, see Peter Grothe, "Norske gymnasiasters holdninger overfor USA" (The Attitudes of Norwegian Senior High School Students to the U.S.A.), Internasjonal Politikk, Oslo, 1972:4, pp. 711-20.

5 Halvdan Koht, Pengemakt og arbeid i Amerika (Money and Labor in America). Oslo, 1910; Genesis o American Independence. Oslo, 1910; Den amerikanske nasjonen i opphav og reising. (The Creation and Rise of the American Nation). Oslo, 1920.

6 The numbers are based on the books included in Norsk Bokfortegnelse (the Norwegian Book Catalogue).

7 Ingrid Semmingsen, En verdensmakt blir til (The Creation of a World Power). Oslo, 1946, p. 423.

8 Ibid., pp. 270, 308-10, 350-352, 393-94, 401-03. 
9 Ibid., pp. 94-95, 178, 270, 302, 305-09, 360. See also S.E. Morison and H.S. Commager, The Growth of the American Republic. 1-2. New York, 1942. Allan Nevins and H.S. Commager, The Pocket History of the United States. New York, 1942.

10 Halvdan Koht, The American S'irit in Europe. A Survey of Transatlantic Influences. Philadelphia, 1949, p. 175. See also pp. V, 2, 16, 59, 124, 144-45, 178-79, 181, 183-84, 186, 202, 207, 242-45, 256, 262, 264, 270-73.

11 Per Vogt, Thomas Jefferson. Oslo, 1946; Abraham Lincoln. Oslo, 1947, see particularly pp. 392-93; Franklin D. Roosevelt. Oslo, 1948, pp. 420-24. But see also pp. 373-74, 414-18 for a more balanced treatment of FDR's role in history.

12. Oliver Blekre Grimley, Amerikas presidenter og historien om deres tid. (America's Presidents and the History of their Times). Oslo, 1945.

13 C.J. Hambro, Amerika pà skilleueien. (America at a Crossroads). Oslo, 1936, pp. 15-30; Powerful America. Oslo, 1939, pp. 6-7, 62-68, 142-43, 159. Torbjørn Sirevåg, "Franklin D. Roosevelt og det moderne Amerilra", (Franklin D. Roosevelt and Modern America) in Bjørn Jensen, ed., Mote med Amerika. 25 nordmenn oppfatter amerikansk historie og ndtid (Rendez-vous with America. 25 Norwegians Interpret the American Past and Present). Oslo, 1976, pp. 51-52.

14 Sigmund Slrard, Amerikanske problem (American Problems). Trondheim, 1949, pp. 10, 36-37, 41, 47-49, 52, 58-59, 64, 104-05, 108-09, 124, 141-42, 146$50,152,156-57,159-60$.

15 Skard, ibid., pp. 158-59.

16 Koht, The American S'irit in Europe, pp. 276-77.

17 The best account of Norwegian foreign policy after the Second World War is Knut E. Erilssen's "Norge i det vestlige samarbeid" (Norway in the Western Community) In Vekst og velstand. Norsk politisk historie 1945-1965. (Growth and Prosperity. Norwegian Political History 1945-1965). Oslo, 1977, pp. 167-278.

18 Johan Galtung and Nils Petter Gleditsch, "Norge i verdenssamfunnet" (Norway in the World Community) in Natalie Rogoff Ramsøy and Mariken Qaa, eds., Det norske samfunn (The Norwegian Society). Oslo, 1975, p. 782.

19 Sigmund Skard, The United States in Norwegian History. Oslo-Westport, 1976, pp. 185-88. In the 1920s and '30s author Sigurd Hoel had been particularly important in bringing contemporary American literature to Norway.

20 Alstad, Norske meninger, I, pp. 110-11, 116-17, 118.

21 The developments referred to in this and the preceding paragraph are described by Skard in this Transatlantica. Memoirs of a Norwegian Americanist. Oslo, 1978, pp. 112-62. See also Skard's Solregn. Ein sjolbiografi (Sun Rain. An Autobiography). Oslo, 1980, pp. 219-43.

22. Sigmund Skard, American Studies in Europe. Their History and Present Organization. Philadelphia, 1958.

23 Ibid.; p. 39. See also pp. 37-43.

24 Skard, Transatlantica, p. 143.

25 Skard, Transatlantica, p. 153; Solregn, pp. 234-35; Interview with Skard in June, 1981; The American Myth and the European Mind was published in Philadelphia in 1961.

26 For Rambro's essay, see his Drommere og dådsmenn (Dreamers and Actors). Oslo, 1945, pp. 108-39.

27 See for instance U.S. Information Service, Moderne kapitalisme. De forente staters okonomi $i$ utvikling. (Modern Capitalism. The Economy of the United States in Development). Oslo, 1957.

28 Sverre Norborg, Det nye Amerika. Hovedstromninger $i$ amerikansk kultur og verdenspolitikk. Oslo, 1958, pp. 126, 129, 132-35. 
29 For the sections on the United States in Aschehoug's Verdenshistorie (Aschehoug's World History), see volume VIP, Oslo, 1957, on the inter-war period, pp. 9-160 particularly pp. 75-76, 83-84, 131, 147, (written by Arne Ording); vol. VIII, Oslo, 1958, on the Second World War and after, pp. 315-32 (Jakob Sverdrup) and 57478 (John Sanness). See also vol. V, Oslo, 1955, covering the period from 1850-1914, pp. 432-69 (John Sanness). See also Tim Greve and Jakob Sverdrup, NATO gjennom ti år (NATO through Ten Years). Oslo, 1959, pp. 9-12, 16-18, 28-29, 32-35 for similar views on the post-war period.

30 Chr.A.R. Christensen, Vair egen tid (Our Own Time). Oslo, 1958. Volume 21 in Grimberg's Menneskenes liv og historie (The Life and Histo y of Man).

31 Skard, Transatlantica, pp. 151-52, 180; Solregn, pp. 234-36.

32 Frede Gastberg, Freedom of Speech in the West. A Comparative Study of Public Law in France, the United States and Germany. Oslo-New York, 1960, particularly pp. 161-62, 171-72, 294, 412. See also his Die Zuständigkeit der Gerichte in USA und Norwegen zur Prüfung der Verfassungsmässigkeit von Gesetzen. Karlsruhe, 1960, pp. 9-10, 18.

33 Norborg, Det nye Amerika, pp. 98-122.

34 See for instance Bjorn Jensen, Mannen $i$ det hvite hus. En orientering om den amerikanske president (The Man in the White House. Information about the American President). Oslo, 1964, pp. 77-78, 84, 98-99, 118-19, 123, 127, 132-33. Sverre S. Amundsen, Den unge presidenten (The Young President). Oslo, 1965.

35 Arne Bonde, U.S.A. Pluss/Minus. Oslo, 1968, see for instance p. 128. Skard was actually quite skeptical of Kennedy, although this was based primarily on a dislike for Kennedy's style and his father's policies. Apparently Skard considered Kennedy a superficial product of his father's money. Interview with Skard in June, 1981. See also Solregn, p. 271.

36 Halvdan Roht, "Når det nye strøymer på" (When the New Bursts Forth), Syn og Segn, (Vision and Myth), 1965, pp. 73-83.

37 Skard, Solregn, p. 271. Interview with Skard in June, 1981.

38 John Ausland, Bak ambassadens murer (Behind Embassy Walls). Oslo, 1979, pp. 105-109.

39 Einar Førde, ed., Amerika og vi (America and We). Oslo, 1969, p. 7. See also pp. 9-11.

40 For a Norwegian account of Watergate, see Tor Strand, Watergate. Et politissk system $i$ krise (Watergate. A Political System in Crisis). Oslo, 1974.

41 Sigmund Skard, USA $i$ norsk historie. Oslo, 1976. (Abbreviated American edition: The United States in Norweegian History. Oslo-Westport, 1976); Skard, "The Image of America in Europe" in A.N.J. den Hollander and Sigmund Skasd, eds., American Civilisation: An Introduction. London 1968, pp. 455-73. 42 Skard, "The Image of America in Europe", p. 471.

43 Skard, The United States in Norwegian History, p. 199.

44 Sigmund Skard, "The American Studies Movement - Problems and Prospects", in USA in Focus. Oslo, 1966, pp. 140-73.

45) Life World Library, The United States. New York, 1965, "Forging a Nation's Soul and Consience", pp. 91-112.

46 Skard wrote several of the sections on American literature for the Scandinavian Verdens Litteraturhistorie (The Literary History of the World). See volume VII, 1800-1830, Oslo, 1972, pp. 281-304; volume VHII, 1830-1860, Oslo, 1972, pp. 375-474; volume IX, 1860-1890, Oslo, 1972, pp. 353-406. See also his anthology of American poetry through 300 years, Under nye stjerner (Under New Stars). Oslo, 1960 and 1979, pp. 5-37 (1979 edition).

47 Skard, Solregn, pp. 242-43, 270-80; Transatlantica, pp. 177-200; The United States in Norwegian History, pp. 192-204; Interview with Skard in June, 1981. 
48 Ingrid Semmingsen, En verdensmakt blir til. Oslo, 1972, pp. 283-91, 312-24, 335-40, 365-66, 369-86, 398-406, 410-14, 425-27, 428-30, 436, 447.

49 Internasjonal Politikk. Det amerikanske samfunn (The American Society). Oslo, 1973: 1B; The quotation is from p. 332. See also pp. 165-67, 169-70, 17478, 203-04, 225-43, 246-60, 261-78, 291.

50 For the racial situation, see for instance Internasjonal Politikk, Oslo, 1973, 1B, Supplement. See also Per Sveino, "Martin Luther King: A Creative Extremist", in Brita Seyersted, ed, Americana Norvegica, IV, Oslo 1973, pp. 361-77. For three theses in American civilization dealing with the situation of blacks, see Ole O. Moen, The Self-Image of the Negro StreetCorner Man. Oslo, 1971; Berit Pinnestad, The Nonviolent Philosophy of Martin Luther King, Jr., Oslo, 1973; Kjell Tore Unhammer, American Jews versus Blacks: Some Aspects of Collision. Oslo, 1975. For a journalisticheroic biography of King, see Welge Christophersen, Sverdet som helbreder. Martin Luther Kings ikke-voldsarmé. (The Sword that Heals. Martin Luther King's Non-Violent Army). Oslo, 1970.

51 Dagbladet, January 12, 1973, pp. 1, 5. Letter from Torbjørn Sirevåg to Geir Lundestad, November 9, 1981.

52 For an example of Rokkan's writings, see his Citizens, Elections, Parties. Approaches to the Comparative Study of the Processes of Development. Oslo, 1970. For Galtung's views, see his "The United States in Indo-China: The Paradigm lor a Generation", in Essays in Peace Research, Volume V, Peace Problems: Some Case Studzes. Copenhagen, 1980, pp. 219-228; See also Galtung's contribution in Orm Overland, ed., America Perceived: A View from Abroad in the 20th Century. West Haven, 1974, pp. 182-90. The quotation is from p. 190.

53 Minerva, Oslo, 1969, 13:1, pp. 4-5 (Gunnar Magnus), 21-28 (Halvor Stenstadvold), 44-57 (Gunnar Magnus). The quotation is from p. 4.

54 Sigmund Skard, "Norsk Amerikaforskning" (Research in Norway on the United States), Forskningsnytt (Research News). Oslo, 1976, 21:8, p. 6. Skard, The United States in Norwegian History, p. 191. Skard's figures have been adjusted by me in part on the basis of Stig Johansson, Audrey Beatty, and Mette-Cathrine Jahr Sørheim, Computer Registration of Hovedfag Theses in English Language, Literature and Civilization in Oslo 1908-80.

55 Sigmund Slrard and Henry R. Wasser, eds., Americana Norvegica. Norwegian Contributions to American Studzes. Philadelphia, 1966; Sigmund Skard, ed., Americana Norvegica. Volume TT. Philadelphia, 1968; Rarald S. Naess and Sigmund Skard, eds., Americana Norvegica. Studies in Scandinavian-American Interrelations. Oslo, 1971; Brita Seyersted, ed., Americana Norvegica. Volume IV. Oslo, 1973. See also Ingrid Semmingsen and Per Seyersted, eds., ScandoAmericana. Papers on Scandinavian Emigration to the United States. Oslo, 1980.

56 The Norwegian edition came out in 1975, the American in 1978, translated by Einar Raugen. For other books on emigration from the mid 1970s, see Lars Chr. Sande, ed., De som dro ut (Those Who Left). Stavanger, 1975; Sverre Norborg, Norge $i$ vesterled (Norway in the West. Oslo, 1974). Einar Hovdhaugen, Frå Venabygd til Texas. Pioneren Jehans Nordbu (From Venabygd to Texas. The Pioneer Jehans Nordbu). Oslo, 1975. Hovdhaugen, ed., Gudbrandsdal og Amerika (Gudbrandsdal and America). Lillehammer, 1975.

57 Oslo, 1976.

58 Jensen, Mote med Amerika, pp. 51-70 (Sirevâg on FDR), 127-33 (Tor Strand on the press), 142-50 (Martin Siem on U.S. management), 151-60 (Haakon Lie on labor unions), 161-68 (Astrid Brekken on feminism), 196-205 (Eivind Reinertsen on the counter culture), even 186-95 (Rune Klakegg on American youth). 
59 Ibid., pp. 5-6 (Bjørn Jensen), 11-24 (Semmingsen), 40-51 (Skårdal), 8395 (Stein Savik on the racial situation).

60 Ibid., pp. 96-109 (Torstein Sandø), particularly p. 109.

61 Polls obtained directly from Norges Markedsdata, published September 30, 1978, May 24, 1980 and Norsk Monitor 1980-unpublished.

62 Skard, Transatlantica; Solregn.

63 Overland, America Perceived; Per Seyersted, Leslie Marmon Silko. Boise, 1980; Ole O. Moen, The Voice of Siouxland; Man and Nature in Frederick Manfred's Writing. Ph.D. dissertation, University of Minnesota, 1978. For a useful thesis on an Indian-related topic, see James Godbolt, American Attitudes to a Modern Indian Uprising: Press Reactions to Wounded Knee 1973. Trondheim, 1979.

64 For an interesting article on the integration of American Studies, see Fredrik Chr. Brøgger, "A Cultural Approach to American Studies", American Studies in Scandinavia, Oslo, 1980, 12:1-2, pp. 1-16.

65 The manuscript is dated 1976.

66 Oslo, 1965, pp. 191-212 are particularly relevant for the American attitude.

67 Oslo, 1970.

68 Oslo, 1972.

69 Americana Norvegica, IV, pp. 379-97. The article was first published in Journal $\oint$ Contemporary History, London, 1970:4, pp. 77-96.

70 Oslo, 1973 and Oslo, 1979.

71 Oslo-New York, 1975 and New York, 1980.

72 Olav Riste, "'The New Left' i amerikansk historieskriving" (The New Left in American Writings of History), Historisk Tidsskrift, Oslo, 1969, 1, pp. 75-87.

73 Ausland, op. cit.

74 Elen C. Singh, The S'itsbergen (Svalbard) Question = United States Foreign Policy, 1907-1935. Oslo, 1980.

75 See for instance Helmer Dahl, Tom Barth and Margaret Joy Tibbetts, HIvorfor forstår vi ikke USA? (Why Don't We Understand the U.S.A.?) Oslo, 1969; Cunne Hammarstrøm, Forrest går enyankee (Up Front You Will Find a Yankee). Oslo, 1969; Harald Dietrich, USA. Et sted eller et begrep? (The U.S.A. A Place or an Idea?). Oslo, 1973. 